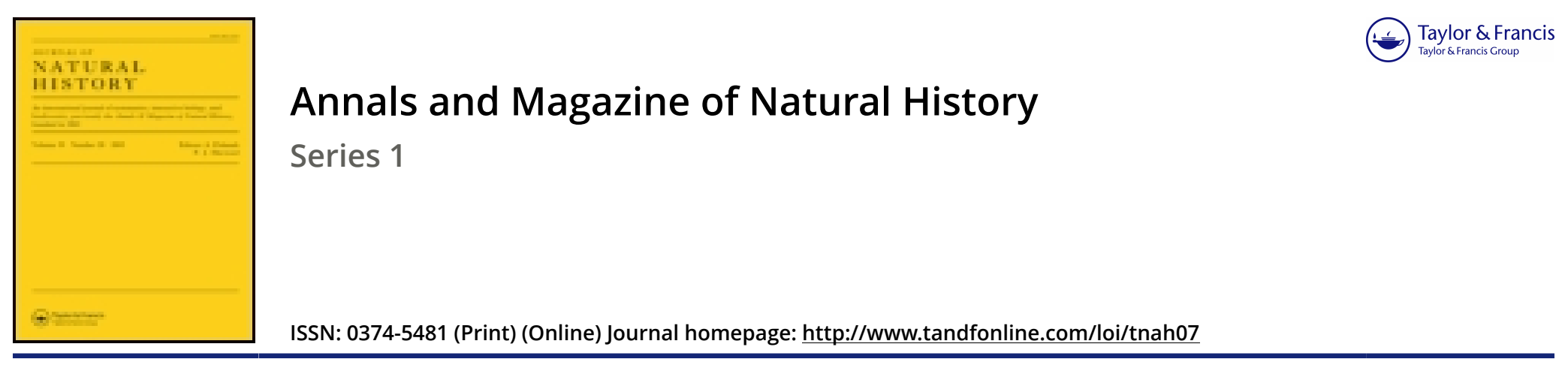

\title{
XLIII.-Description of a new genus of Carabideous Insects brought from the Falkland Islands by Charles Darwin, Esq.
}

\section{G. R. Waterhouse Esq.}

To cite this article: G. R. Waterhouse Esq. (1843) XLIII.-Description of a new genus of Carabideous Insects brought from the Falkland Islands by Charles Darwin, Esq., Annals and Magazine of Natural History, 11:70, 281-283, DOI: 10.1080/03745484309445304

To link to this article: http://dx.doi.org/10.1080/03745484309445304

曲 Published online: 04 Dec 2009.

Submit your article to this journal $\pi$

View related articles ¿ 
one, two are usually larger than the rest. On the lower series the tubercles are usually more numcrous than on the upper.

Under surface. - The triangular spaces between the arenues are granulated; among the granulations numcrous large stomata, in form linear and compressed, cach placed in a smooth space surrounded by a close border of flattened mammiform tubercles, those forming the lateral borders largest. The arenues are linear, contracting towards the arms. Suclers biserial. Border of avenues formed by transverse plates, each bearing four or five elongated tubercles, two of which face the avenue. 'These plates are each bordered by a series of granules.

Eye-cover formed of one large transversely-ovate tubcrele terminating the ray, and three or four smaller oncs on each side, with a circle of minute granules immediately surrounding the (red) eye.

Dimensions.-Breadth across the dise $5 \frac{1}{2}$ inches ; length of arm $1 \frac{3}{15}$ inch; breadth of arm at base $\frac{?}{10}$ inch.

Colour.-When fresh Mr. Maclaurin states it was of an orange-yellow, which with crimson-red, are the usual hues of the Cushion-stars. Dried, it is of a pale yellow.

\section{EXPLANATION OF PLATE VII.}

Fig. 1. The starfish, secn from above.

Fig. 2. Portion of upper surface.

Fig. 3. Ditto of under surface.
Fig. 4. Marginal plates.

Fig. 5. Border of avenuc.

Fig. G. Eye-corcr.

XLIII.-Description of a new genus of Carabideous Insects brought from the Falklanel Islands by Charles Darwin, Esq. By G. R. Watennouse, Esq., Assistant Sccretary and Curator' to the Zoological Society, \&c.

\section{Section GEODEPHAGA. Fam. FEIRONIIDE. \\ Lissorterus*, nov, gen.}

Corpus depressum, elongatum; lateribus elytrorum subparallelis.

Labrum transversum, antice emarginatum.

Labium profunde cmarginatum, dente in mclio paulo producto, ad apicem truncato.

Palpi filiformes, articulo, ultimo ad apicem truncato.

Mandibulc mediocres, cdentula, acutac.

Antenna mediocres, articulis subrqualibus.

Pcles mediocres; tibic anteriores in maribus incrassatx, ct tarsi articulis quatuor dilatati.

This genus is founded upon an insect discovered by Mr.Dar-

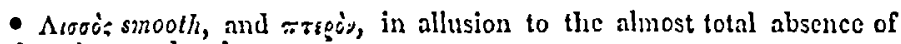
sculpturing on the clytra. 
win in the Falkland Islands. Some of the speaimens were found in the month of March under a dead bird on the sea-coast in E. Falkland Island. Both by mysclf and Mr. Darwin this insect was upon a cursory inspection supposed to be a species of Sphodrus, but upon cxamination it was found to exhibit characters which separate it from that and other published genera. 'The more conspicuous are, the swollen anterior tibiac of the male; the femora are also stoutcr in this sex, and the four basal joints of the anterior tarsi are dilated, and (with the exception of the basal joint, which is triangular;) they are broader than long. The antenne do not exhibit the short second and long third joint as in Sphodines, but have the joints all nearly equal in length, the second joint being scarcely shorter than the third, which is not longer than the following joints. In size the present insect is about equal to the $\mathrm{Oma-}$ scus melanurus, and an idea of its proportions may perhaps be best conveyed by comparing the two: the body is more depressed than in 0 . melanurus, the head is a trifle broader, and the antennae are more slender; the thorax presents nearly the same outline, but the sides are not rounded quite to the base as in that insect. The elytra also present nearly the some outline, but besides being less convex, they have the reflected margin much broader and more distinct ; the legs are nearly of the same proportions; the dilated tarsi of the male are broader, the tibize stouter, and the internal emargination much less distinct, and situated nearer to the apex of the tibia. The principal specific characters may be thus expressed:-

Lissopterus quadrinotatus. Liss. niger subnitidus; antennis pedibusque piceis, vel rufo-piceis; thorace supra paulo convexo, subquadrato postice angustiore, lateribus indistincte rotundatis, foreis duabus oblongis impresso, medio canaliculato; clytris elongatoovatis, lateribus subparallelis postice rotundatis, supra subdepressis, leribus, indistinctissime striatis, notis quatuor rufis ornatis. Long. corp. $60-8$ lin.; lat. $25-3$ lin.

$V a r . \beta$. Elytris immaculatis, pedilus nigris.

Colour. black; hend and thorax glossy, elytra dull ; head rather broad and subdepressed, with a slight transverse groove in front marking the posterior boundary of the clypeus, which is transverse and slightly cmarginated in fiont, where it is of a pitchy hue; two shallow fovea situated partly on the clypcus and partly on the head; eyes rather small, rounded and convex; labrum and mandibles pitchy; antennx and palpi pitchy-red. Thorax about one-fourth bronder than long; in front but little narrower than the elytra, and behind about one-fifth narrower than in front; the sides slightly rounded, but becoming ncarly straight and parnilel towards the postcrior 
angles, which are nearly right angles; the upper surface is but little convex, the reflected lateral margins are rather broad, the dorsal channel moderately distinct, but obliterated near the anterior and postcrior margins of the thorax; on each side, behind, are two oblique, long, smooth forcx, between which is a transverse impression situated at about one-fourth of the distance from the base towards the apex of the thoraxthis transverse impression is not strongly marked. Elytra clongate-ovate, above subdepressed, the lateral reflected margins broad and distinct, the surface nearly smooth but cxhibiting indistinct stria, and these are most faintly punctured; two smallish red spots are obscrvable on cach elytron near the outer margin, one towards the base of the elytron, and the other on the apical fourth; the legs are pitchy or pitchy-red. Sometimes the red spots on the elytra are obliterated, the legs are nearly black, nnd the antenne and palpi are pitchy.

Obs. - As rergards one of the characters upon which I found the present genus, I allude to the male sex having four of the joints of the anterior tarsi distinctly dilated, I may call attention to the remark by Dejean in his observations on the Feronic, viz. that this group is distinguished from the $\mathrm{Har}$ pali by the structure of the intermediate tarsi (i.c. they are not dilated), and by the fourth joint of the anterior tarsus, which is never dilated in the male sca. The genus Lissopterus therefore affords a remarkable exception to a general rule.
XLIV.-The Birds of Ireland By Wr. Thompson, Esq., Pres. Nat. Hist. Society, Belfast.
[Continued from sol. x. p. 170.]

The Rivg-Dove*-Columba Palumbus, Linn,-is common throughout the wooded districts of the island.

Mr. Waterton is rather disposed to believe that in his part of Yorkshire there is an annual increase by migration to the numbers of native birds. Mr. Selby states, in gencral terms, that there is not any such increase. The grent numbers that congregate in auturn, and remain together during winter in Ireland, I have always considered as our indligenous birds only, collected together in their choicest haunts, howerer widely scparated they may hare been in the breeding-scason.

Belroir l'ark near Belfast, with its fine and extensive woods, is quite a preserve for these birds, and throughout the autumn and winter they may be daily seen there in the aftemoon, in multitudi-

- Commonly called Wood Quest and Wood l'jgeon in the north of Ireland. 